\title{
Manfaat Penerapan Standar pada Perusahaan Tuna di DKI Jakarta
}

\author{
The Study of Standard Application in Tuna Company in DKI Jakarta
}

\author{
Retno Dwiputri Linthin ${ }^{1}$, Fransiska R. Zakaria ${ }^{2}$, dan Wini Trilaksani ${ }^{3}$ \\ ${ }^{1}$ Kementerian Kelautan dan Perikanan \\ 2 Departemen Ilmu dan Teknologi Pangan Fakultas Teknologi Pertanian, Institut Pertanian Bogor \\ Jl. Kamper Kampus IPB Darmaga Bogor 16680 \\ ${ }^{3}$ Departemen Teknologi Hasil Perairan Fakultas Perikanan dan Ilmu Kelautan, Institut Pertanian Bogor \\ Jl. Agatis, Kampus IPB Darmaga Bogor 16680
}

\begin{abstract}
ABSTRAK
Tuna merupakan salah satu komoditas perikanan yang paling berharga di Indonesia. Sebagian besar produksi ikan tuna di Indonesia di ekspor ke beberapa negara tujuan seperti jepang, Uni Eropa, dan Amerika. Permintaan tuna di Jepang dan Amerika Serikat dari tahun ke tahun tidak pernah menurun. Selanjutnya, peran industri tuna dari waktu ke waktu semakin penting dan strategis, terutama dalam mempertahankan ekonomi bangsa karena ikan tuna berperan penting dalam kesehatan masyarakat dimana ikan tuna menyediakan protein berkualitas tinggi. Agar produk tuna dapat diterima dan diminati oleh konsumen, maka valuable creative activities perlu dirumuskan agar sumberdaya yang kita miliki (tangible, intangible, human resources) dapat menghasilkan produk yang berkompetensi baik di dalam maupun luar negeri. Produk perikanan prima dapat dihasilkan apabila industri perikanan menerapkan beberapa standar baik yang nasional maupun internasional seperti ISO, SNI, CODEX, dan standar dari importir. Agar perusahaan dapat menerapkan standar, maka perlu kajian beberapa manfaat dari penerapan standar. Terkait dengan standar yang diterapkan oleh perusahaan maka akan dilakukan kajian terhadap manfaat dari penerapan standar di industri tuna yang ada di Muara Baru, DKI Jakarta. Tujuan penelitian ini untuk mengkaji manfaat penerapan standar di perusahaan tuna. Metode yang digunakan adalah deskriptif dan menggunakan beberapa pengujian termasuk analisis rasio profitabilitas (net profit margin, return on asset, return on equity, profit margin). Hasil penelitian ini adalah bahwa kedua perusahaan telah menerapkan standar baku, pemahaman standar oleh kedua perusahaan masih ada yang berbeda, sedangkan dari sektor keuangan perusahaan mampu meningkatkan keuntungan.
\end{abstract}

Kata kunci: kelayakan perusahaan, profitabilitas, standar, Tuna

\begin{abstract}
Tuna is one of the most valuable fishery commodities produced in Indonesia. In a great measure of tuna production in Indonesia is exported to several destination countries such as Japan, the European Union and America. The demand for tuna in Japan and the United States from year to year has never decreased. Furthermore, the role of tuna industry from time to time is increasingly important and strategic, especially in sustaining the nation's economy as tuna plays an important role in many people's health in which Tuna provides high quality protein. In terms of sustainable tuna consumption, valuable creative activities (VCA) is required to be formulated, so all resources (tangible, intangible, human resources) are able to produce prime fishery products that have high quality standard and high value content, competent, safe, traceable, both nationally and internationally. The Prime fishery products are able to be produced if the fishery industry successfully applies several standards both national and international such as ISO, SNI, CODEX, and standards from importers. In terms of applying those standards, it is worth reviewing few of benefits of standard implementation. Associated with the standards applied by the company, there are studies of the benefits of standard implementation in tuna industry in Muara Baru, DKI Jakarta. The purpose of this study was to assess
\end{abstract}

\footnotetext{
*) Korespondensi:

Gedung Mina Bahari I, Jl. Medan Merdeka Timur No. 16, Gambir, Jakarta Pusat 10110: email: rlinthin@yahoo.com
} 
the benefits of standard implementation in tuna companies. The method used was descriptive and it uses several tests including profitability ratio analysis (net profit margin, return on asset, return on equity, profit margin). The results of this study are that both companies had implemented the standard well, standard understanding by both companies still exist different, while from the financial sector the company was able to increase profits.

Key words: company feasibility, profitability, standard, Tuna

\section{PENDAHULUAN}

Tuna merupakan salah satu komoditas perikanan yang banyak dihasilkan di Indonesia. Data statistik Kementerian Kelautan dan Perikanan menunjukkan bahwa produksi perikanan tangkap di laut untuk komoditas ikan tuna dari tahun 2009 sampai dengan tahun 2014 mengalami kenaikan rata-rata 2,7 ton per tahun. Data volume ekspor tahun 2014-2016 untuk produk ikan tuna beku sebesar 32.837 ton pad tahun 2014, 22.185 ton pada tahun 2015, dan 22.282 ton pada tahun 2016 (www.trademap.org). Indonesia mengekspor produk ikan tuna mayoritas ke beberapa negara tujuan seperti Jepang, Uni Eropa, dan Amerika. Dalam rangka meningkatkan kualitas produk ikan tuna dan memberikan jaminan kepada konsumen, maka perlu untuk menjaga keamanan pangan dan mutu produk.

Salah satu upaya yang dilakukan untuk memberikan jaminan keamanan pangan kepada konsumen adalah dengan menerapkan standar. Dalam UU No 20 tahun 2014 tentang standarisasi dan penilaian kesesuaian dijelaskan bahwa standar adalah persyaratan teknis atau sesuatu yang dibakukan, termasuk tata cara dan metode yang disusun berdasarkan konsensus semua pihak/pemerintah internasional terkait, dengan memperhatikan syarat keselamatan, keamanan, kesehatan, lingkungan hidup, perkembangan IPTEK, pengalaman, serta perkembangan masa kini dan masa depan untuk memperoleh manfaat sebesar-besarnya. Pada sektor perikanan dasar hukum yang mengatur tentang penerapan standar adalah Keputusan Menteri Kelautan dan Perikanan Nomor 52A tahun 2013 tentang persyaratan jaminan mutu dan keamanan hasil perikanan pada proses produksi, pengolahan dan distribusi; dan Keputusan Menteri Kelautan dan Perikanan Nomor 08 tahun 2014 tentang pemberlakuan penerapan Standar Nasional Indonesia (SNI). Dalam kaitannya dengan perdagangan internasional, maka produk pangan yang diperdagangkan harus memenuhi persyaratan yang berlaku di negara tujuan ekspor antara lain syarat mutu, keamanan, lingkungan, kesehatan, dan lain-lain. Hal yang sama juga berlaku untuk produk impor. Penerapan standar akan berdampak pada terciptanya pasar yang tersegmentasi, peningkatan kekuatan pasar dari pelaku, serta menguatkan entry barries (Salim, 2012).

Tuntutan akan jaminan keamanan pangan yang tinggi, perlu diantisipasi oleh industri pangan di Indonesia, tidak hanya dalam rangka mengantisipasi meningkatnya persyaratan keamanan pangan yang akan diberlakukan oleh negara pengimpor tetapi terutama dalam rangka memberikan jaminan keamanan pangan bagi konsumen. Saat ini industri pangan tidak hanya bertanggung jawab memproduksi makanan yang aman tetapi juga dapat menunjukkan secara transparan bagaimana keamanan pangan telah direncanakan dan terjamin.

Herjanto (2011) menyatakan bahwa efektivitas penerapan SNI wajib sudah cukup memadai namun masih banyak terdapat kelemahan di berbagai aspek yang perlu ditingkatkan. Hambatan utama yang dihadapi produsen dalam penerapan SNI wajib antara lain keterbatasan sumberdaya manusia, kesulitan untuk mengkalibrasikan peralatan laboratorium maupun produksi, biaya sertifikasi yang relatif mahal, dan kepedulian konsumen terhadap standar yang masih kurang. Mensah et al. (2011) menyatakan bahwa hambatan penerapan Hazard Analysis Critical Control Point (HACCP) adalah biaya pengembangan dan implementasi sistem HACCP. Berdasarkan penelitian Pudjiastuti et al. (2010) menunjukkan bahwa secara umum dua belas peubah pengukur manfaat sertifikasi secara bersama-sama memperlihatkan adanya kecenderungan manfaat. Motivasi terbesar melakukan sertifikasi karena dorongan dari pimpinan manajemen, responden tidak mengalami kesulitan dalam menerapkan sistem manajemen dan perolehan sertifikasi dan biaya sertifikasi masih dianggap wajar.

Kondisi perusahaan perikanan di Indonesia saat ini masih belum secara keseluruhan dapat menerapkan standar yang diberlakukan oleh 
pemerintah maupun persyaratan dari negara pengimpor. Hal ini disebabkan karena perusahaan belum yakin akan manfaat yang diberikan dari penerapan standar dan besarnya biaya yang akan dikeluarkan untuk memenuhi semua persyaratan. Hal ini dapat berdampak kepada mutu yang dihasilkan sehingga tidak dapat memberikan jaminan kepada konsumen dan menurunnya persaingan pasar. Penelitian ini bertujuan untuk mengkaji manfaat penerapan standar bagi industri.

\section{METODE PENELITIAN}

\section{Pengumpulan Data}

Metode pengumpulan data meliputi: Studi pustaka, Wawancara menggunakan kuesioner, Observasi. Sumber data terdiri dari: (1) Data Primer (profil perusahaan, data aktivitas keuangan perusahaan dan data pendukung produksi); (2) Data Sekunder berasal dari eksternal perusahaan seperti KKP, BPS, melalui penelusuran buku, jurnal, tesis, literatur dari internet dan artikel lainnya yang berkaitan dengan topik kajian.

Penelitian ini menggunakan kuesioner likert dengan nara sumber adalah karyawan dari PT Mahkota Jaya Sejahtera dan PT Awindo Internastional. Metode penentuan contoh yang digunakan adalah purposive sampling dengan 10 narasumber untuk setiap perusahaan. Matriks penelitian ini disajikan pada Tabel 1.

\section{Analisis Data}

1. Analisis Kelayakan Perusahaan

Analisis secara deskriptif ini bertujuan menilai kondisi perusahaan yang telah memenuhi prinsip dasar pengolahan, yang meliputi konstruksi, tata letak, higiene, seleksi bahan baku dan teknik pengolahan. Analisis ini berdasarkan pada Peraturan Menteri Kelautan dan Perikanan nomor 72 tahun 2016.

\section{Analisis Profitabilitas}

a. Net Profit Margin (NPM)

Net Profit Margin ini menunjukkan pendapatan bersih yang dapat di capai setiap penjualan. Rasio ini bermanfaat untuk menunjukkan seberapa kemampuan manajemen dalam menghasilkan pendapatan untuk mengendalikan pabrik, operasi dan pinjamanpinjaman perusahaan. Laba bersih yang diperoleh juga tergantung pada kebijakan pemerintah mengenai tingkat suku bunga dan pajak penghasilan yang akan mengurangi laba bersih yang di peroleh perusahaan. NPM dikatakan baik apabila $>5 \%$.

b. Return On Investment (ROI)

Return on investment adalah rasio yang digunakan untuk mengukur kemampuan perusahaan dalam menghasilkan laba yang berasal dari aktivitas investasi Mardiyanto (2009: 196). Rasio ini mengukur kemampuan perusahaan dalam menghasilkan laba operasi dengan semua aktiva yang dimiliki oleh perusahaan.

c. Return on Equity (ROE)

Return on equity atau sering disebut rate of return on network merupakan salah satu teknik yang dapat digunakan dalam memperhitungkan profitabilitas perusahaan independent terhadap dana yang di pakai. ROE merupakan indikator untuk mengukur keberhasilan manajemen dalam melakukan tugasnya yakni menghasilkan modal yang maksimal.

\section{d. Profit Margin}

Profit Margin adalah salah satu analisa ratio untuk mengukur tingkat kenaikan laba suatu perusahaan, pada kebanyakan analisis dalam suatu perusahaan menganggap ratio ini adalah rangkuman dari rasio-rasio profitabilitas lainnya untuk mengukur apakah suatu perusahaan memperoleh profit atau tidak.

Tabel 1. Matriks penelitian

\begin{tabular}{|c|c|c|c|}
\hline No & Tujuan & Sumber Data & Alat analisis \\
\hline 1 & $\begin{array}{l}\text { Mengkaji kelayakan } \\
\text { perusahaan }\end{array}$ & $\begin{array}{ll}\text { - } & \text { Kuisioner penilaian kelayakan perusahaan } \\
\text { - } & \text { Volume produksi perusahaan }\end{array}$ & \\
\hline 2 & $\begin{array}{l}\text { Mengkaji standar yang } \\
\text { digunakan oleh } \\
\text { perusahaan }\end{array}$ & $\begin{array}{l}\text { Kuesioner data unit pengolahan yang telah } \\
\text { disediakan dan diisi oleh perusahaan }\end{array}$ & Analisis deskriptif \\
\hline 3 & $\begin{array}{l}\text { Mengkaji manfaat } \\
\text { penerapan standar yang } \\
\text { diperoleh perusahaan }\end{array}$ & $\begin{array}{l}\text { - Kuisioner penerapan standar yang telah } \\
\text { disediakan dan diisi oleh perusahaan } \\
\text { - } \quad \text { Data keuangan perusahaan } \\
\text { - } \quad \text { Data reject perusaan dan negara }\end{array}$ & Analisis profitabilitas \\
\hline
\end{tabular}




\section{HASIL DAN PEMBAHASAN}

\section{Penilaian Kelayakan Perusahaan}

Salah satu persyaratan perusahaan perikanan dapat melakukan usaha pengolahan adalah harus memiliki Sertifikat Pengolahan Ikan (SKP). Penilaian kelayakan perusahaan dilakukan menggunakan kuisioner yang berdasarkan pada Permen no 72 tahun 2016 tentang persyaratan dan tata cara penerbitan SKP. Aspek yang di nilai meliputi manajemen dan teknis, adapun klausul yang dinilai antara lain: komitmen manajemen; lingkunan; bangunan; penataan dan pemeliharaan lingkungan; penerimaan bahan baku/penolong/ tambahan; bahan pembungkus dan pengemas; penyimpan-an produk (sesuai perlakuan); air; es; peralatan dan perlengkapan yang kontak dengan produk; fasilitas pencucian produk; konstruksi dan tata letak proses; kebersihan ruangan dan peralatan pengolahan; fasilitas karyawan; bahan kimia dan bahan berbahaya; limah padat dan limbah berbahaya; pengemasan dan pelabelan; kebersihan dan kesehatan karyawan; peningkatan kemampuan/ketrampilan SDM; pengendalian binatang pengganggu; instalasi pengolahan air limbah (IPAL).

Hasil penilaian kelayakan perusahaan PT Mahkota Samudera Jaya dan PT Awindo Internasional masuk dalam kategori layak karena telah mampu mengikuti persyaratan SKP. Kedua perusahaan ini belum memiliki IPAL tetapi tidak menjadi masalah karena air limbah langsung di kelola oleh perum perindo, sedangkan untuk limbah padat sudah ada pihak yang menampung.

\section{Penerapan SNI}

Salah satu standar yang berlaku di Indonesia adalah Standar Nasional Indonesia (SNI). Produk yang dihasilkan oleh perusahaan harus sesuai dengan SNI. Penerapan standar di PT Mahkota Jaya Sejahtera dan PT Awindo International mengikuti SNI produk tuna beku, yang dilakukan mulai dari:

1. Penerimaan bahan baku

- SNI 01-2710.1-2006 tentang spesifikasi ikan tuna

- SNI 01-2710.2-2006 tentang bahan baku ikan tuna

- GMP dan SSOP

2. Pengolahan

- SNI 01-2710.3-2006 tentang penanganan dan pengolahan ikan tuna

- Persyaratan dari buyer

\section{- GMP dan SSOP}

3. Pengemasan

- SNI 01-4110.1-2006 tentang spesifikasi ikan beku

- SNI 01-4110.2-2006 tentang persyaratan bahan baku

- SNI 01-4110.3-2006 tentang penanganan dan pengolahan ikan beku

- GMP dan SSOP

4. Penyimpanan

- SNI 01-4110.3-2006 tentang penanganan dan pengolahan ikan beku

- GMP dan SSOP

5. Distribusi

- SNI 01-4110.3-2006 tentang penanganan dan pengolahan ikan beku

- GMP dan SSOP

Penerapan standar negara importir di PT. Mahkota Jaya Sejahtera dan PT Awindo Internasional mencakup dari negara-negara tujuan ekspor yaitu: Amerika, Jepang, Korea, Eropa dan Vietnam.

Dalam penerapan standar negara importir, kedua perusahaan tidak pernah mengalami permasalahan. Negara importir mengirimkan tim inspeksi untuk mengecek produk yang akan di kirim ke negara mereka sehingga tidak terjadi penolakan.

Penerapan standar di perusahaan membutuhkan biaya yang banyak, tetapi tidak memberatkan perusahaan karena mereka berpikir hal itu demi perbaikan industri ke depan dan dapat menurunkan biaya operasional serta meningkatkan laba. Hal ini disampaikan juga oleh Gunawan (2009: 116) bahwa pentingnya pelaku industri dalam negeri untuk menerapkan Sistem Manajemen Mutu (SMM), karena Sistem Manajemen Mutu bukanlah berarti penambahan biaya namun merupakan usaha perbaikan terus menerus dalam mengurangi pemborosan ataupun meningkatkan usaha pencegahan produk jelek.

Pemahaman tentang penerapan standar di perusahaan harus secara menyeluruh yaitu dimulai dari pihak manajemen sampai ke para karyawan. Hal ini telah dilakukan juga oleh kedua perusahaan, di mana semua karyawan wajib mematuhi peraturan yang diberlakukan serta adanya pelatihan kepada karyawan agar mereka mengetahui pentingnya menerapkan standar

Sejalan dengan hasil penelitian Herjanto (2011) yang menyatakan bahwa efektifitas penerapan SNI wajib sudah cukup memadai 
namun masih banyak terdapat kelemahan di berbagai aspek yang perlu ditingkatkan, pemahaman karyawan akan pentingnya sanitasi di kedua perusahaan ternyata sedikit berbeda. Hasil analisis menghasilkan bahwa adanya perbedaan antara kedua perusahaan, yaitu pada segi manfaat dan perubahan dari penerapan standar serta perlunya pengawasan untuk mengevaluasi standar yang telah diterapkan.

\section{Manfaat Standar}

Manfaat standar internal perusahaan akan dirasakan oleh internal perusahaan, pemasok, dan pelanggannya. Apabila perusahaan ingin produk/ jasanya dapat diterima secara luas, perusahaan perlu menerapkan standar dengan tingkatan yang lebih tinggi seperti standar asosiasi, standar nasional dan satndar internasional. Penerapan standar dengan standar yang lebih tinggi dapat menjadi hambatan apabila perusahaan tidak siap melakukan penyesuaian.

Penerapan standar melibatkan banyak pihak yang berbeda sehingga dapat memberikan manfaat kepada pihak tersebut. Standar memberikan manfaat bagi negara, pelaku bisnis dan konsumen. Indikator yang dapat digunakan untuk melihat manfaat standar adalah peningkatan volume produksi perusahaan, peningkatan data ekspor indonesia, dan peningkatan profit perusahaan dan adanya data reject.

\section{Peningkatan Profit}

Perhitungan nilai ekonomi dari hal apa pun termasuk kegiatan standarisasi yang sesuai dengan prinsip ekonomi. Prinsip ekonomi ini mempertimbangkan cost dan benefit, yaitu bagaimana membuat kebetuhan terpenuhi dengan sebaik mungkin dengan biaya yang sesedikit mungkin. Perkembangan perusahaan dan laba yang di capai perusahaan dapat digunakan sebagai alat ukur terhadap keberhasilan perusahaan dalam menjalankan aktivitas yang berkenaan dengan operasinya. Jika tujuan perusahaan itu tercapai maka kelangsungan hidup perusahaan mampu bersaing dengan perusahaan lain.

PT Awindo Internasional dan PT Mahkota Jaya Sejahtera adalah perusahaan yang bergerak di bidang pangan khususnya perikanan. Industri ini sudah sejak awal menerapkan beberapa standar negara pengimpor termasuk Standar Nasional Indonesia (SNI). Penerapan standar ini diharapkan dapat meningkatkan laba perusahaan. Kondisi ekonomi PT Awindo International dan PT
Mahkota Jaya Sejahtera dapat dilihat melalui analisa profibilitas yaitu dengan Net Profit Magin (NPM), Return on Equity (ROE), Return on Investment (ROI), dan Profit Margin.

Analisa profitabilitas PT Mahkota Jaya Sejahtera menunjukkan bahwa perusahaan tersebut efektif dalam meningkatkan keuntungan dalam 3 tahun terakhir. Pada tahun 2015 dan 2016 mengalami penurunan karena adanya peraturan moratorium, tetapi hal ini tidak mengakibatkan perusahaan tersebut tidak mampu beroperasi. Hasil analisis profitabilitas PT Mahkota Jaya Sejahtera ditunjukkan pada Gambar 2.

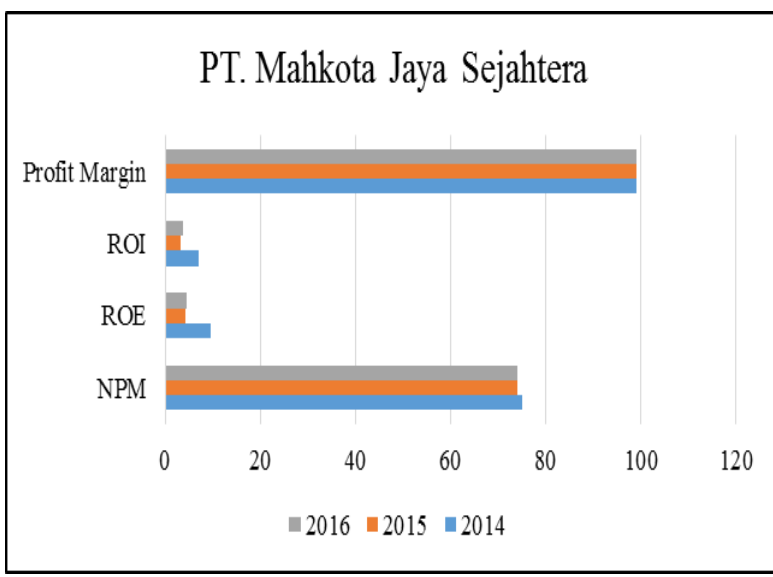

Gambar 2. Grafik Profitabilitas PT Mahkota Jaya Sejahtera

Analisa profitabilitas PT Awindo Jaya Sejahtera juga menunjukkan bahwa perusahaan telah efektif dalam meningkatkan keuntungan. Nilai profitabilitas perusahaan tersebut relatif stabil. Perusahaan tersebut memiliki kapal penangkap sendiri sehingga mampu menangkap ikan untuk produksi sendiri. PT Awindo memiliki nilai ROE dan ROI yang lebih besar daripada PT Mahkota, hal ini disebabkan oleh besarnya laba setiap tahun yang di terima tidak seimbang dengan total ekuitas setiap tahunnya. Hasil analisis profitabilitas PT Awindo International ditunjukkan pada Gambar 3.

\section{Data Reject (Penolakan)}

Manfaat standar dapat berupa dampak sosial, lingkungan dan ekonomi, kemudian dampak standar dapat digolongkan menjadi dapat di hitung dan tidak dapat di hitung. Dampak standar berpengaruh kepada hasil nilai audit perusahaan, PT Mahkota Jaya saat ini memiliki HACCP grade B sehingga belum bisa melakukan ekspor ke Eropa sedangkan PT Awindo Jaya Sejahtera memiliki nilai HACCP A sehingga dapat melakukan ekspor ke Eropa. 


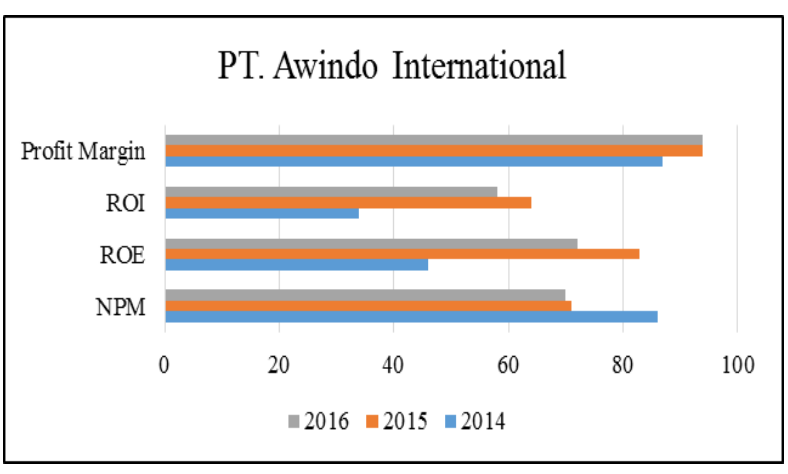

Gambar 3. Grafik Profitabilitas PT Awindo International Sejahtera

Berkurangnya reject produk suatu perusahaan atau negara merupakan salah satu indikator bahwa manfaat standar di perusahaan telah berjalan dengan baik. Data reject PT Mahkota Jaya Sejahtera dan PT Awindo International dari tahun 2014-2016 disajikan pada Tabel 2. Data reject PT Awindo International disebabkan adanya pencemaran logam berat pada produk oilfish, bukan pada produk ikan tuna.

Tabel 2. Data reject perusahaan tahun 2014 - 2016

\begin{tabular}{lccc}
\hline \multirow{2}{*}{ Perusahaan } & \multicolumn{3}{c}{ Tahun } \\
\cline { 2 - 4 } & 2014 & 2015 & 2016 \\
\hline PT Mahkota Jaya Sejahtera & - & - & - \\
PT Awindo International & - & - & 1 \\
\hline
\end{tabular}

\section{Peningkatan Volume Produksi}

Volume produksi dapat dijadikan acuan bahwa suatu perusahaan itu telah menerapkan standar dengan baik. Faktor-faktor yang memengaruhi peningkatan volume produksi adalah mutu produk yang terjamin kualitasnya, sumber daya manusia yang terampil dan memahami stndar, banyaknya bahan baku, sarana prasarana yang cukup memadai dan permintaan dari buyer yang terus meningkat. Faktor-faktor ini apabila diikuti dengan penerapan standar yang baik maka volume produksi pun akan meningkat. Penurunan volume ekspor tuna di Indonesia pada tahun 2015 lebih disebabkan oleh adanya kebijakan moratorium. Hal ini berdampak pada penurunan produksi hasil olahan dan waktu beroperasinya unit pengolahan ikan. Hal ini pun disampaikan oleh Hikmayani et al. (2015) bahwa kebijakan moratorium menunjukkan kurang efektif untuk peningkatan kinerja usaha pengolahan khususnya usaha pengolahan skala besar.

PT Mahkota Jaya Sejahtera ikut merasakan dampak dari moratorium pada tahun 2014 terlihat pada tren volume produksi yaitu $-0,29$, yang menunjukkan penurunan dari tahun 2014 sebanyak 500 ton ke tahun 2015 menjadi 300 ton. PT Awindo Internasional tidak merasakan dampak moratorium tersebut. Hal ini terbukti dengan tren yang meningkat yaitu 1,43. Grafik volume produksi PT Mahkota Jaya Sejahtera dan PT Awindo International disajikan pada Gambar 4. Penerapan standar pada PT Mahkota Jaya Sejahtera tidak termasuk penyebab turunnya volume produksi melainkan karena perusahaan tersebut memiliki kapal penangkap ikan yang ukurannya $>30 \mathrm{GT}$.

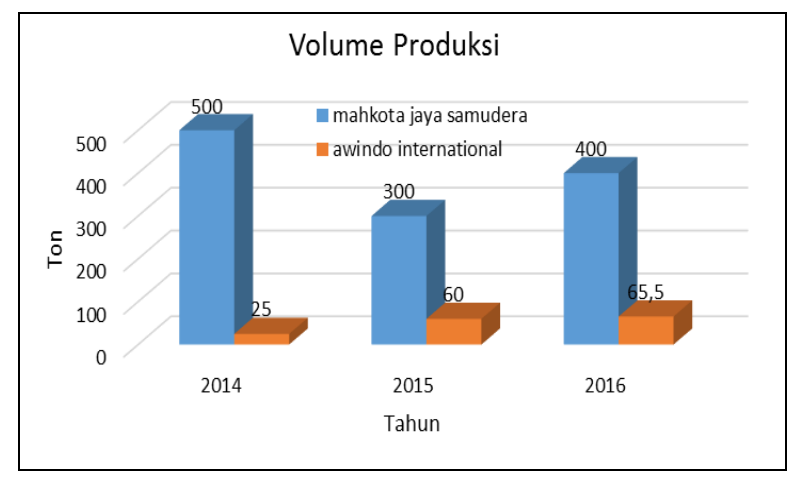

Gambar 4. Volume produksi perusahaan tahun 2014-2016

\section{KESIMPULAN}

1. Perusahaan yang mampu berkomitmen menerapkan standar dalam dan luar negeri dapat memberikan manfaat bagi perusahaan itu sendiri, konsumen dan negara.

2. Semakin tinggi standar yang diterapkan, semakin banyak komitmen dan waktu yang diperlukan dalam proses pengembangannya secara berkelanjutan.

\section{DAFTAR PUSTAKA}

Hikmayani, Y., R. Rahardian, Nurlailii, R. Muhartono. 2015. Efektivitas Pemberlakuan Kebijakan Moratorium Kapal Eks Asing dan Transhipment terhadap Kinerja Usaha Penangkapan Ikan. Jurnal Kebijakan Sosek KP Vol. 5 no. 2 tahun 2015. Balai Besar Penelitian Sosial Ekonomi Kelautan dan Perikanan. Jakarta

Herjanto, E. 2011. Pemberlakuan SNI Secara Wajib di Sektor Industri: Efektifitas dan Berbagai Aspek Dalam Penerapannya. Jurnal Riset Industri Vol. V. No. 2. Hal 121-130. 
Keputusan Menteri no 8 tahun 2014 tentang Pemberlakuan Penerapan Standar Nasional Indonesia Produk perikanan.

Keputusan Menteri no 52A tahun 2013 tentang persyaratan jaminan mutu dan keamanan hasil perikanan pada proses produksi, pengolahan dan distribusi.

List of Importing Markets for a Product Group Exported by Indonesia. [Internet]. [diunduh 18 September 2017]. Tersedia pada: www.trademap.org.

Mensah, L.D., D. Julien. 2011. Implementation of Food Safety Management System in the UK Food Control. 22.1216-1225.

Peraturan Menteri Kelautan dan Perikanan no. 72 tahun 2016 tentang Persyaratan dan Tata Cara Penerbitan Sertifikat Kelayakan Pengoahan.
Pudjiastuti, U., D.V. Femina. 2010. Manfaat Sertifikasi Bagi Industri di Indonesia. Jurnal Standarisasi Volume 12 no 2. Jakarta. Badan Standarisasi Nasional. Hlm. 106-117.

Pusdatin. 2014. Kelautan dan Perikanan Dalam Angka. Kementerian Kelautan dan Perikanan. Jakarta.

Salim, Z. 2012. Standarisasi Produk Perikanan dan Olahannya Dalam Penguatan Pasar Ekspor. Lembaga Ilmu Pengetahuan Indonesia (LIPI), Pusat Penelitian Ekonomi (P2E).

Undang-Undang Republik Indonesia Nomor 20 Tahun 2014 tentang Standardisasi dan Penilaian Kesesuaian. 